\title{
Om ungdomsfanger og recidiv
}

\author{
Nogle resultater fra en kriminografisk unders $\phi$ gelse $^{1}$ )
}

\author{
Af vidensk. ass., cand. jur. VAGN GREVE
}

Ungdomsfængsel er siden 1955 blevet en forholdsvis hyppigt anvendt sanktion ${ }^{2}$ ). Baggrunden for den stedfundne udvikling har i højere grad været ideologiske og humanitære betragtninger end empiriske unders $\phi$ gelser. Denne artikel skal beskrive ungdomsfangerne og deres recidivfaktorer. Man kan ikke umiddelbart bed $\phi$ mme ungdomsfængslernes arbejde og betydning ud fra disse oplysninger; men de er en del af det nødvendige grundlag for en stillingtagen til denne sanktionsform. Kriminalpolitisk set er det uheldigt, at recidivunders $\varnothing$ gelser n $\varnothing$ dvendigvis må baseres på ældre årgange. Der foreligger endnu ikke nogen beskrivelse af de mulige forskelle mellem de ældre årgange og de nuværende ungdomsfanger. Der findes heller ikke nogen mulighed for at påvise virkningerne af nye og ændrede behandlingsformer. Resultaterne kan derfor ikke med tilstrækkelig sikkerhed benyttes som prognose for de for tiden indsatte.

Unders $\phi$ gelsen er koncentreret om recidivfaktorerne. Ved en faktor forstås en hvilken som helst variabel, der manifesterer sig på en umiddelbart eller middelbart iagttagelig måde, og som kan beskrives kvalitativt eller kvantitativt ${ }^{3}$ ). En recidivfaktor er en faktor, der optræder i lovmæssig sammenhæng med recidiv. Recidivfaktorer er ikke n $\varnothing$ dvendigvis almindelige kriminalitetsfaktorer. Alderen er f. eks. en kriminalitetsfaktor i den samlede danske befolkning, men beh $\phi$ ver ikke derfor at være en recidivfaktor. Ved recidiv forstås en handling, der udløser en strafferetlig reaktion, herunder genindsættelse ${ }^{4}$ ). Af praktiske grunde bygger nærværende undersøgelse udelukkende på oplysninger, der forelå ved eller umiddelbart efter indsættelsen $i$ ungdomsfængslernes modtagelsesafdeling.

1) Artiklen er baseret på min utrykte afløsningsopgave: ,137 ungdomsfængselsfanger. Nogle resultater fra en unders $\varnothing$ gelse af recidiv-
faktorer." 1963 .

2) Jfr. f. eks. B. Paludan-Müller: „Pædagogisk terapi af sociale afvigere. Det lukkede ungdomsfængsel" i Nyborg“, Juristen 1965, s. 49 ff.

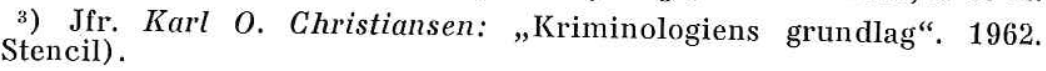

4) Med hensyn til tidspunktet for recidiv anvendes tidspunktet for den f $\varnothing$ rste registrerede strafbare handling efter pr $\phi$ vel $\varnothing$ sladelsen uden hensyn til, om den er blevet efterfulgt af en sanktion. 
Materialet er de 137 unge mænd, der i årene 1953-54 blev indsat i ungdomsfængslet if $\varnothing$ lge dom. Oplysningerne hidrører især fra ungdomsfængslernes meget fyldige fangechartequer. Disse indeholder bl. a. mentalunders $\phi$ gelser, personunders $\phi$ gelser, domsudskrifter og rapport over modtagelsesafdelingens leders bes $\phi \mathrm{g}$ i fangens hjem. Recidivet blev registreret pr. 1. december 1962 i Rigsregistraturen. Tiden fra f $\phi$ rste pr $\phi$ vel $\phi$ sladelse til registreringen af recidivet varierer fra ca. 9 år til ca. 5 år.

\section{R E C I D I V}

Af de 137 ungdomsfanger er $49 \%$ blevet genindsat, $60 \%$ er blevet id $\phi \mathrm{mt}$ fængsel, $10 \%$ arbejdshus, forvaring eller særfængsel og endelig er $21 \%$ blevet underkastet andre strafferetlige reaktioner. Kun $18 \%$ har ikke senere været udsat for en kriminalretlig sanktion.

Tabel 1. Recidivet.

$\begin{array}{lrr}\text { Genindsættelse } & 67 & 49 \% \\ \text { Fængsel } & 82 & 60 \% \\ \text { Arbejdshus } & 2 & 1 \% \\ \text { Forvaring/særæængsel } & 13 & 9 \% \\ \text { Andre sanktioner } & 29 & 21 \% \\ \text { Ingen senere sanktioner } & 25 & 18 \%\end{array}$

Det er ikke muligt at konstruere et anvendeligt almindeligt recidivbegreb. Det er rimeligt at betragte genindsættelse som recidiv ved visse sammenligninger med de almindelige statsfængsler og andre institutioner. På den anden side må man erkende, at det kan være rimeligt at betragte genindsættelse som et naturligt led i ungdomsfangslets behandling. Jeg har derfor opgivet det hyppigt anvendte unuancerede recidivbegreb til fordel for en inddeling i recidivgrupper.

Recidivgruppe $A$ omfatter de genindsatte, der ikke desuden er blevet d $\phi \mathrm{mt}$ til fængsel, arbejdshus, forvaring eller særfængsel.

Recidivgruppe $B$ består af de fanger, der både er blevet genindsat og id $\varnothing \mathrm{mt}$ en af de under recidivgruppe A nævnte andre sanktioner.

Recidivgruppe $C$ er de ikke-genindsatte, der er blevet d $\phi \mathrm{mt}$ til en af de under recidivgruppe A nævnte andre sanktioner.

Recidivgruppe $D$ omfatter de ikke-genindsatte, der heller ikke er blevet d $\varnothing \mathrm{mt}$ til nogen af de under recidivgruppe A nævnte andre reaktioner. 
Recidivgruppe A vil typisk rumme de mere bagatelagtige tilbagefald. Man kan intet sige om grupperne B og C's indbyrdes forhold.

Gruppe D omfatter både fanger, der ikke er registreret for senere kriminalitet, og dem der kun har fået bøde, hæfte og lignende. Til trods for betegnelsen recidivgruppe rummer gruppen altså også probander, der ikke er recidiveret. Endelig indeholder den sanktioner, der ofte betragtes som recidiv, f. eks. anbringelse på statshospital i henhold til straffelovens $\S 70$. Denne placering er formentlig den rimeligste, idet man håber, at ungdomsfængslernes behandling kan forhindre senere alvorlige forbrydelser, men ikke at den kan forebygge sindssygdomme.

I recidivgrupperne $\mathrm{B}$ og $\mathrm{C}$ findes henholdsvis $36 \%$ og $28 \%$ af fangerne; recidivgruppe A udg $\phi \mathbf{r} 13 \%$ og recidivgruppe D $23 \%{ }^{5}$ ).

Tabel 2. Recidivgrupperne.

$\begin{array}{lrr}\text { Recidivgruppe A } & 18 & 13 \% \\ \text { Recidivgruppe B } & 49 & 36 \% \\ \text { Recidivgruppe C } & 38 & 28 \% \\ \text { Recidivgruppe D } & 32 & 23 \% \\ \text { I alt } & 137 & 100 \%\end{array}$

\section{A L D E R}

Den dagældende straffelovs $\S 41$ krævede, at unge, der id $\varnothing$ mtes ungdomsfængsel, skulle være mellem 15 og 21 år på forbrydelsens tidspunkt. I praksis anvendtes ungdomsfængsel hovedsageligt over for de 18-19 årige. Domstolene var meget tilbageholdende med at dømme personer under 18 år til ungdomsfængsel. Dette skete i reglen kun, når børneforsorgens opdragelsesmidler blev anset for virkningsløse. De 15-17 årige er mere belastede end de ældre; de har i højere grad voldt problemer i skolen og på opdragelseshjemmet. Der ses imidlertid ingen umiddelbar sammenhæng mellem alderen og tilbagefaldet.

\section{K R I M I N A L I T E T}

Kun få af fangerne kan kriminologisk betegnes som ,rene typer“" ${ }^{\prime \prime}$. Langt de fleste har overtrådt flere forskellige lovbestem-

5) Der findes ingen tilgængelig officiel opgørelse over disse årganges recidiv. Til sammenligning kan anføres, at Beretning om Fængselsvæsenet $i$ Danmark $1956 \circ \mathrm{g} 195 \%, 1959$, s. $130 \mathrm{ff}$., oplyser, at af de i årene $1945-48$ løsladte ungdomsfanger recidiverede $42,4 \%$ til særforanstaltninger eller fængselsstraf, og at Beretning om Fængselsvesenet $i$ Danmark 1961, 1964, s. 104, angiver, at $64,8 \%$ af de i $19561 \varnothing \mathrm{s}-$ ladte ungdomsfanger falder tilbage til særforanstaltning, fængsel eller genindsættelse.

$\left.{ }^{6}\right)$ Jfr. Stephan Hurwitz: „Kriminologi“, 1951, s. 415. 
melser. Selv om det samme gerningsindhold er realiseret, vil handlingerne dog hyppigt forekomme kriminologisk uensartede. Sprængning af pengeskabe og tyveri fra moderens tallerkenrække vil formentlig, uagtet begge dele bed $\phi$ mmes som tyveri, i mange henseender være væsensforskellige. Man må derfor i nogen grad opgive de juridiske sondringer. For at få et klart billede er der kun registreret de kvalitativt og kvantitativt dominerende kriminalitetsarter. En del er registreret med flere dominerende kriminalitetsarter.

Berigelsesforbrydelserne er mest fremtrædende. Indbrud i forretning er for halvdelens vedkommende en dominerende kriminalitetsart. Tyveri fra andre lettilgængelige steder end automater, arbejdspladser og lignende dominerer hos $1 / 3$.

\section{Tabel 3. Kriminalitetsarten.}

$\begin{array}{lrr}\text { Brugstyveri } & 38 & 28 \% \\ \text { Indbrud i forretning } & 66 & 48 \% \\ \text { Indbrud i villa } & 20 & 15 \% \\ \text { Automattyveri } & 19 & 14 \% \\ \text { Indbrud i sommerhus } & 25 & 18 \% \\ \text { Arbejdspladstyveri } & 16 & 12 \% \\ \text { Tyveri fra andet lettilgængeligt sted } & 48 & 35 \% \\ \text { R } \varnothing \text { mningskriminalitet } & 37 & 27 \% \\ \text { Anden berigelseskriminalitet } & 16 & 12 \% \\ \text { Vold } & 9 & 7 \% \\ \text { Sexualkriminalitet (herunder } & & \\ \text { homosexuel prostitution) } & 5 & 4 \% \\ \text { Andet } & 15 & 11 \%\end{array}$

De ungdomsfanger, der har begået den væsentlige kriminalitet i forbindelse med r $\phi$ mninger fra børnehjem eller andet, er relativt ofte $\mathrm{i}$ recidivgruppe $\mathrm{B}$ og sjældent $\mathrm{i} \mathrm{D}$.

$50 \%$ er registreret for kriminalitet f $\varnothing \mathrm{r}$ det 14 . år. Det er naturligvis lidet rimeligt at sondre mellem straffebestemmelser og andre normer, når der er tale om børn; men hvis dette kriterium ikke anvendes, må man bruge for løse og subjektive sk $\phi$ n. De tidligt kriminelle har f $\phi \mathbf{r}$ ungdomsfængselsopholdet vist sig upåvirkelige af børneværnets opdragelsesmidler (lange ophold på mange institutioner, negative udtalelser fra disse, mange r $\varnothing \mathrm{m}-$ ninger). Det kan derfor ikke undre, at de i ringe grad påvirkes af ungdomsfængslernes behandling, der i et vist omfang ligner opdragelseshjemmenes.

De, der var 14-16 år ved den f $\phi$ rste registrerede kriminalitet, har den bedste prognose, ca. $43 \%$ er i gruppe D. Måske er deres kriminalitet et udtryk for pubertetskonflikter. 
De sent begyndte er ofte dårligt begavede, alkoholmisbrugere og har børn udenfor ægteskab. De synes at have været relativt modtagelige for behandling.

Antallet af forhold $i$ ungdomsfrngselssagen siger intet om den aktuelle kriminalitet, da der i sagen hyppigt er medtaget en række forhold, der tidligere er givet tiltalefrafald for. De fleste fanger har under 20 forhold; kun 6 har over 50 forhold, heraf én med over 100. De fanger, der har flest forhold, recidiverer hurtigt og hyppigt.

\section{T I L T A E F R A F A L D O G F OR S TR A F F E}

En trediedel har ikke f $\varnothing \mathbf{r}$ dommen til ungdomsfængsel fået tiltalefrafald, en fjerdedel har fået ét, en femtedel to og en femtedel flere end to. Næsten alle tiltalefrafaldene er givet med hjemmel i straffelovens (nu ophævede) $§ 30$.

De, der ikke har fået tiltalefrafald, er fortrinsvis provinsboere, der ikke har været undergivet b $\phi$ rneværnet, men som tidligere er blevet id $\varnothing \mathrm{mt}$ betinget eller ubetinget fængsel. Deres prognose er gunstig; de er hyppigst i recidivgruppe D.

Probander med få tiltalefrafald er begyndt med kriminalitet sent og har (derfor) ikke så hyppigt været undergivet børneforsorg; de har i stedet domme på betinget eller ubetinget fængsel. Hvis de har været på opdragelseshjem, har de været der længe. Deres arbejdsforhold er ringe (negative arbejdsgivererklæringer, hyppigt arbejdsl $\phi s e)$. De recidiverer ofte til fængsel.

Fanger med mange tiltalefrafald er hyppigt $k \phi$ benhavnere med dårlige forhold $\mathrm{i}$ hjemmet (belastede fædre, fors $\phi$ mmelig opdragelse), i skolen (hjælpeskole, negative skoleudtalelser) og til børneværnet (undergivet børneværnet på grund af egne forhold, stor interneringstæthed, mange institutionsophold, mange r $\varnothing \mathrm{m}$ ninger). De er temmelig gamle ved indsættelsen i ungdomsfængslet (19-20 år) og recidiverer hurtigt og hyppigt, især til genindsættelse.

Tabel 4. Forstraffe.

$\begin{array}{lll}\text { Uafsonet betinget frihedsstraf } & 35 & 26 \% \\ \text { B } \varnothing \text { de } & 15 & 11 \% \\ \text { Fængsel } & 18 & 13 \% \\ \text { Forstraffe, i alt } & 58 & 42 \%\end{array}$

Godt halvdelen har, som det fremgår af tabel 4, ingen forstraffe. De har til gengæld været i konflikt med børneværnet (tidligt kriminelle, mange delikter, fjernet fra hjemmet, stor interneringstæthed, mange romninger, mange institutionsophold, 
lang tid på institution). Deres arbejdsforhold er dårlige (kort tid på arbejdspladserne, negative arbejdsgiverbed $\varnothing$ mmelser). De recidiverer hurtigt.

De 15, der har fået b $\emptyset$ der, har især været brugstyve. Alle 15 er faldet tilbage under en eller anden form.

\section{B Ø R N V Æ R N S F R H O L D}

Kun $13 \%$ af probanderne har ikke været undergivet børneforsorg. $60 \%$ har været fjernet fra hjemmet på grund af egne forhold.

Tabel 5. Bழ่rneværnsforhold.

Ikke under børneværnet

Tilsyn på gr. af egne forhold

Tilsyn på gr. af hjemmets forhold

Fjernet på gr. af egne forhold

Fjernet på gr. af hjemmets forhold
18

74

11

82

13
$13 \%$

$54 \%$

$8 \%$

$60 \%$

$9 \%$

Fanger, der ikke har været under børneværnet, er begyndt sent på kriminalitet. Deres forhold i barndommen har været relativt gode (ikke i hjælpeskole, ikke skulket, normale opdragerkonstellationer); men de har mange delikter og/eller tidligere fængselsstraffe. De falder ikke så hurtigt tilbage som de andre.

De, der har haft tilsyn af børneværnet på grund af hjemmets forhold, er, som det kunne ventes, hyppigt registreret med negative hjemfaktorer ( $\varnothing \varnothing \mathrm{dt}$ uden for ægteskab ${ }^{7}$ ), brudt hjem, mange opdragerkonstellationer, belastede forældre, fors $\phi$ mmelig opdragelse). Der er gode muligheder for resocialisering.

Probander, der er fjernet på grund af egne forhold, er ofte begyndt på kriminalitet tidligt. Fanger, der har været fjernet fra hjemmet på grund af dettes forhold, kommer fra meget ringe hjem. De har ofte været på mange opdragelseshjem i lang tid. Begge grupper recidiverer hyppigt til fængsel.

I materialet er der registreret over 60 institutioner; langt de fleste optræder dog kun én eller to gange. De hyppigst forekommende er Bråskovgård (25), Flakkebjerg (17), Skibby (13) og Stengården (13). En trediedel af fangerne har ikke været på opdragelseshjem, og en trediedel har været på tre eller flere.

De 47 probander, der ikke har været på hjem, har kun få præsumptivt negative registreringer. Deres prognose er gunstig, recidivgrupperne A og D dominerer. Det samme gælder dem, der kun har haft få institutionsophold. De har tilpasset sig godt på hjemmene (kort tid, få rømninger, positiv vurdering).

7) Jfr. Lov om offentlig Forsorg, nr. 181 af 20. maj 1933, § 118. 
De, der har været på flere institutioner, er børneværnets problemb $\phi \mathbf{r n}$ (mange rømninger med kriminalitet, lang tid på opdragelseshjemmene) fra dårlige hjem (straffede forældre, fors $\varnothing$ mmelig opdragelse, tidligt fjernet fra hjemmet). De er unge ved indsættelsen $\mathrm{i}$ ungdomsfæengslet og recidiverer hurtigt - især til grupperne B og C.

Halvdelen af fangerne er af opdragelseshjemmet blevet bed $\varnothing \mathrm{mt}$ negativt og kun en femtedel har fået en positiv vurdering.

Tabel 6. Institutionens helhedsvurdering.

$\begin{array}{lll}\text { Positiv vurdering } & 17 & 19 \% \\ \text { Negativ vurdering } & 48 & 53 \% \\ \text { Neutral vurdering } & 13 & 14 \% \\ \text { Uoplyst } & 12 & 13 \% \\ \text { I alt } & 90 & 99 \%\end{array}$

De positivt vurderede er fortrinsvis i recidivgruppe $\mathrm{C}$, medens de negativt bed $\varnothing$ mte især er i grupperne $\mathrm{A}$ og $\mathrm{B}$.

Godt en trediedel har været 3 år eller derover på hjem, og en tilsvarende gruppe har været der mellem 1 og 3 år.

Tabel 7. Tid på institutionen.

$\begin{array}{lrr}\text { Uoplyst og under } 1 \text { år } & 18 & 20 \% \\ 1-3 \text { år } & 35 & 39 \% \\ 3 \text { år eller derover } & 37 & 41 \% \\ \text { I alt } & 90 & 100 \%\end{array}$

Fangens følelse af tilpasning på institutionen fremgår i nogen grad af antallet af rømninger.

Tabel 8. Antal rømninger.

$\begin{array}{llr}\text { Uoplyst eller ingen r } \phi \text { mninger } & 20 & 22 \% \\ 1-4 \text { r } \phi \text { mninger } & 29 & 32 \% \\ \text { Over } 4 \text { r } \phi \text { mninger } & 41 & 46 \% \\ \text { I alt } & 90 & 100 \%\end{array}$

Fanger, der kun er rømt få gange, har en god prognose - fortrinsvis recidivgruppe $D$. Probander med mange rømninger har også på andre måder voldt børneværnet kvaler. De recidiverer hurtigt og hyppigt til gruppe B. For at udelukke tidsfaktoren er rømningshyppigheden beregnet, som antal måneder på institutionen delt med antal r $\phi$ mninger. Der er for ringe spredning til, at faktoren kan anvendes. 


\section{N T E R N E R I N G S T E T H E D}

Ved internering forstås en anbringelse på en institution, der er af en sådan art, at anbringelsen hyppigt vil blive betragtet som en straf eller en straflignende sanktion (f. eks. fængsel og opdragelseshjem). Anbringelsen skal typisk medf $\varnothing$ re en afsondring fra omverdenen. Det kræves ikke, at institutionaliseringen i det konkrete tilfælde har karakter af sanktion. Derfor medtages anbringelse på børnehjem på grund af forældrenes forhold. Det

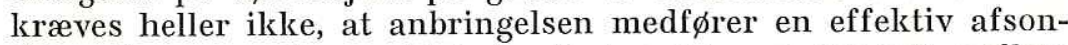
dring fra omverdenen, idet der f. eks. ikke er sondret mellem børnehjem, hvor undervisningen foregảr på institutionen, og hjem, hvor eleverne bes $\varnothing$ ger den almindelige folkeskole ${ }^{8}$ ). Ved interneringstiden (it) forstås den tid, som fangen har tilbragt interneret indtil anholdelsen $i$ anledning af den sag, der resulterede $\mathrm{i}$ den aktuelle dom til ungdomsfængsel ${ }^{9}$ ). Ved $\mathrm{Ft}$ forstås tiden fra første internerings påbegyndelse til anholdelsen i ungdomsfængselssagen.

Ved interneringstæthed i relation til levetiden (IL) forstås:

$$
\text { it } \cdot 100
$$

Alder ved anholdelsen i ungdomsfængselssagen.

Ved interneringstæthed fra første internering (IF) forstås:

$$
\frac{\text { it } \cdot 100}{\mathrm{Ft}}
$$

Forskellen på IL og $\mathrm{IF}^{10}$ ) kan muligvis, omend noget forenklet, udtrykkes således: IL er et udtryk for den kumulerede institutionspåvirkning. Et stort IL viser således, at personen har fảet en lang behandling. IF står $i$ en art omvendt forhold til institutionsanbringelsernes positive resultat. Et lavt IF er m.a.o. et udtryk for, at institutionernes behandling har haft en positiv og $\mathrm{h} \varnothing \mathrm{j}$ effektivitet, medens et $\mathrm{h} \phi \mathrm{jt}$ IF viser, at institutionerne hidtil har været lidet effektive. Det må antages, at denne tolkning forudsætter, at fangen har været institutionaliseret adskillige gange, muligvis mindst $4-5$ gange.

8) Det anvendte interneringsbegreb er videre end det af Karl $O$. Christiansen i „Kriminelle levnedsl $\phi \mathrm{b} “$, NTFS 1942, s. 11 anvendte.

$\left.{ }^{9}\right)$ Jfr. Karl O. Christiansen: „Kriminelle levnedsløb“, NTFS 1942, s. $14 \mathrm{ff}$.

10) Både IL og IF afviger fra det af Karl O. Christiansen anvendte interneringstæthedsbegreb, Itt, jfr. ,Kriminelle levnedsl $\varnothing \mathrm{b} “$, NTFS 1942 , s. $14 \mathrm{ff}$. 
Tabel 9. Interneringstæthed.

IL:

0

$0-10$

$10-30$

$30-$

I alt

IF :

0

$0-40$

$40-70$

$70-99$

100

I alt
37

40

49

11

137

37

24

34

25

17

137
$27 \%$

$29 \%$

$36 \%$

$8 \%$

$100 \%$

$27 \%$

$18 \%$

$25 \%$

$18 \%$

$12 \%$

$100 \%$

Fanger med IL $=0$ kommer fra gode hjem med én opdragerkonstellation og har fået gode udtalelser fra skolen. De har kun fået få tiltalefrafald og har ikke begået mange lovovertrædelser. Prognosen er relativt god; mange kommer i recidivgruppe D.

Probander med store IL er svært belastede. De kommer fra ringe hjem (f $\varnothing \mathrm{dt}$ uden for ægteskab, belastede m $\phi$ dre, mange opdragerkonstellationer). De har negative udtalelser fra skole og opdragelseshjem. De er tidligt begyndt på kriminalitet og har begået mange delikter, herunder indbrud i forretninger. De falder hurtigt og hyppigt tilbage, især til gruppe A eller fængsel.

De med store IF har ret meget kriminalitet (mange tiltalefrafald, forretningsindbrud, rømningskriminalitet) og mange problemer i forholdet til børneværnet (hyppigt under børneværnet, negative vurderinger fra opdragelseshjemmene, mange r $\varnothing$ mninger). Det er hyppigt k $\phi$ benhavnere fra tilsyneladende gode hjem. De recidiverer hyppigt til recidivgruppe $B$.

En vurdering af IL og IF som arbejdsredskaber synes at falde ud til fordel for IL, idet denne - i hvert fald i disse aldersklasser - giver en bedre spredning af de relevante faktorer. Det er dog sandsynligt, at man ved fors $\phi \mathrm{g}$ på prædiktion eller lignende må anvende en kombination.

\section{F A M I L I E F O R H O L D O G O P D R A E L S E}

$22(16 \%)$ er født uden for ægteskab. Det synes i denne forbindelse at være uden betydning.

Ved et brudt hjem forstås hjem, hvor opdragernes ægteskab er opl $\phi$ st ved $d \varnothing d$ eller skilsmisse, eller hvor der foreligger retslig 
separation, selv om denne ikke efterf $\varnothing$ lges af en faktisk, eller faktisk separation af over $1 / 2$ års varighed, når denne skyldes den ene eller begge ægtefællers $\phi$ nske om at afbryde det ægteskabelige samliv. Hvis en fanges hjem er brudt mere end én gang, er alderen ved første brud anvendt.

Tabel 10. Brudt hjem.

Hjemmet ikke brudt

Hjemmet brudt, $0-8$ år

Hjemmet brudt, $9-16$ år

I alt
89

21

27

137
$65 \%$

$15 \%$

$20 \%$

$100 \%$

Probander med brudt hjem har meget ringe hjemforhold (belastede fædre, mere end to opdragerkonstellationer, fors $\phi \mathrm{mmelig}$ opdragelse, negativt hjem) og har været lang tid på opdragelseshjem. Det kan dog ikke udelukkes, at de mange negative oplysninger om fædrene giver et fortegnet billede. Når man f. eks. til en personunders $\phi$ gelse får oplyst, at fangens forældre er skilt eller separeret, sp $\phi$ rger man normalt fangen og/eller hans forældre om grunden hertil. Derved kan man få oplysninger om en episodisk kriminalitet eller drikfældighed, som man ikke ville have h $\varnothing$ rt om, hvis ægteskabet ikke var blevet opl $\phi$ st. Det er i denne forbindelse ikke uden betydning, at alkoholmisbrug ikke sjældent benyttes som separationsgrund af hustruer, når ægteskabet af andre grunde er $\phi$ delagt. Det kan dog ikke udelukkes, at der er en kvalitativ forskel på de registrerede og de ikke-registrerede. Da de registrerede sandsynligvis ofte har været en medvirkende årsag til ægteskabets opløsning, vil de måske være grovere.

Tabel 11. Opdragerkonstellationer. Art.

Naturlig moder og fader

Naturlig moder alene

Naturlig moder og stedfader

Naturlig fader alene

Naturlig fader og stedmoder

Plejehjem eller adoption

Børnehjem og lignende

Andet (herunder slægtninge)

$\begin{array}{rr}111 & 81 \% \\ 35 & 26 \% \\ 19 & 14 \% \\ 11 & 8 \% \\ 6 & 4 \% \\ 11 & 8 \% \\ 42 & 31 \% \\ 25 & 18 \%\end{array}$

Fanger fra hjem, der er brudt, medens fangen var mellem 9 og 16 år, er hyppigt opdraget af de naturlige forældre og knyttet til moderen. Kriminaliteten er begyndt sent og har især vist sig som tyveri fra lettilgængelige steder. Deres forhold på opdragelseshjemmene har været gode (få rømninger, positiv vurdering). 
Prognosen er god, idet de recidiverer langsomt og især er $\mathrm{i}$ gruppe D.

Opdragerkonstellationsarterne fremgår af tabel 11.

Man får dog et bedre indtryk af fangernes kår under opvæksten, når man betragter antallet af opdragerkonstellationer. Knap halvdelen har indtil det fyldte 15 år kun haft én opdragerkonstellation, medens $1 / 4$ har haft tre eller flere.

De af de naturlige forældre opdragede er fraflyttet hjemmet sent og har været temmelig gamle ved kriminalitetens begyndelse. De er hyppigt i gruppe D.

Fanger, der er opdraget af faderen og stedmoder, er hyppigt fra hjem med høj status. De har ofte skulket fra skolen. De recidiverer fortrinsvis til gruppe $B$.

Børnehjemsbørnene er fra familier med lav status, er blevet fors $\varnothing \mathrm{mmeligt}$ opdraget, er tidligt blevet asociale (tidlig kriminalitet, skulkeri) og har været på mange opdragelseshjem. Fortrinsvis recidivgruppe $\mathrm{C}$.

Formentlig er opdragernes art og antal af underordnet betydning for personlighedsudviklingen sammenlignet med klimaet $i$ hjemmet og opdragelsesformen. $1 / 3$ af fangerne må anses for fors $\varnothing$ mmeligt opdraget og $1 / 3$ har fået en skiftende opdragelse. $1 / 4$ er særlig knyttet til moderen. Jfr. nærmere tabel 12.

Tabel 12. Opdragelsen.

Streng, ukærlig opdragelse

Forsømmelig opdragelse

Overbeskyttende opdragelse

Skiftende opdragelse

Særlig knyttet til, faderen

Særlig knyttet til moderen

Ingen klassifikation
16

46

19

51

6

35

32
$12 \%$

$34 \%$

$14 \%$

$37 \%$

$4 \%$

$26 \%$

$23 \%$

De fors $\phi$ mmeligt opdragede kommer fra dårlige hjem (drikfældig fader, enlig moder, flere opdragerkonstellationer, negative hjem), er hyppigt under børneværnet og har været på flere opdragelseshjem. De recidiverer hyppigt og især til gruppe C.

Fanger, der særligt er knyttet til moderen, er fortrinsvis k $\phi$ benhavnere, er født uden for ægteskab og har mange opdragerkonstellationer. De har negative skoleudtalelser. De recidiverer sjældent til fængsel.

Det er derefter unders $\emptyset$ gt om forældrene i en eller anden henseende må anses for belastede. Det er formentlig ret tilfældigt om noget sådant oplyses, og akternes kilder virker ofte lidet troværdige. Da det her er forældrenes påvirkning af barnet, der har interesse, er den omtalte fader eller moder kun den naturlige, 
hvis denne har opdraget probanden $\mathrm{f} \phi \mathrm{r}$ dennes fyldte 16. år. Hvis dette ikke er tilfældet, vedrører det her registrerede den person, der er trådt i stedet. Hvis flere har gjort dette, er der lagt vægt på tiden og tidspunktet. $1 / 3$ har belastede fædre $\operatorname{og}^{1} / 6$ har belastede m $\phi$ dre, medens $3 / 5$ efter det oplyste hverken har belastede fædre eller mødre. For fædrenes vedkommende er sindssyge og åndssvage samlet under betegnelsen psykisk afvigende. Den tilsvarende gruppe omfatter for mødrenes vedkommende også drikfældige.

Tabel 13. Forældrenes belastning.

Faderen:

Straffet

Psykisk afvigende

Drikfældig

Ubelastet

30

4

27

90

Moderen:

Straffet

Psykisk afvigende

Prostitueret

Ubelastet
11

9

9

113

Faderen og moderen:

Ubelastet
$22 \%$

$3 \%$

$20 \%$

$66 \%$

$8 \%$

$7 \%$

$7 \%$

$82 \%$

$59 \%$

De forskellige faktorer, der vedrører hjemmet og opdragelsen, er indbyrdes stærkt korrelerede, men synes kun at have ringe sammenhæng med andre faktorer.

Familiens sociale status under fangens opvækst er registreret på grundlag af Kaare Svalastogas inddeling ${ }^{11}$ ). De lavere klasser dominerer.

Tabel 14. Familiens sociale status.

Lavere arbejderklasse

Mellemste arbejderklasse

Højere arbejderklasse

I $\phi$ vrigt

I alt
38

61

29

9

137
$28 \%$

$45 \%$

$21 \%$

$7 \%$

$101 \%$

Lav status er forbundet med belastede forældre (straffede og drikfældige fædre, straffede og prostituerede m $\phi$ dre) og desuden med negativt milieu og dårlige hjem (enlig moder, negativt, over-

11) Jfr. Kaare Svalastoga og Preben Wolf: „Social rang og mobilitet", 1961. 
befolket og brudt hjem, fors $\phi$ mmelig opdragelse). Disse fanger har været på flere opdragelseshjem og er relativt hyppigt dårligt begavede. De genindsættes ofte. Probander fra højere arbejderklasse er hyppigt i recidivgruppe D.

De ovennævnte faktorer vedrører alle opvæksten. Det er imidlertid muligt, at det er forholdene på løsladelsestidspunktet, der primært har betydning for recidivet. Jeg har derfor s $\phi$ gt at sk $\varnothing$ nne over hjemmets værdi for resocialiseringen af fangen. Sk $\phi$ nnet er i det væsentlige baseret på ungdomsfængslets rapporter over bes $\phi \mathrm{g}$ i hjemmet, men også mentalundersøgelser m. m. er taget i betragtning.

Der synes at være en tendens til, at de mentalunders $\varnothing$ gende læger bed $\phi$ mmer hjemmet hårdere end den bes $\phi$ gende ungdomsfængselsfunktionær (i reglen lederen af ungdomsfængslernes modtagelsesafdeling). Om årsagerne hertil kan man kun gisne. Måske er der kun tale om en anden terminologi. Mentalundersøgelserne er ikke sjældent farvet af et ordvalg, der for en ikkepsykiater kan synes temmelig hårdt. Denne sprogbrug kan måske accentuere hjemmets negative sider. Muligvis har den i ungdomsfængslet ansatte et bedre kendskab til фkonomisk dårlige hjem; han ved hvordan selv et godt arbejdsmands- eller husmandshjem kan se ud, når der kommer uanmeldt besøg. Endelig kan det tænkes, at psykiateren s $\phi$ ger at finde årsagerne til kriminaliteten, hvorfor han vil koncentrere sig om de negative sider, medens ungdomsfængslet pr $\phi$ ver at finde ud af, hvordan hjemmet vil kunne st $\varnothing$ tte fangen under pr $\phi$ vel $\varnothing$ sladelsen $^{12}$ ). I forbindelse hermed står det, at psykiateren koncentrerer sig om barndomshjemmet, medens ungdomsfængslet i f $\varnothing$ rste række interesserer sig for hjemmets nuværende kvalitet; de fleste hjem virker formentlig bedre, når børnene er vokset op og de $\phi$ konomiske forhold derfor er blevet forbedret.

Godt halvdelen af hjemmene blev anset for negative, medens kun $17 \%$ betragtedes som positive. Dette kan ikke undre; hjemmene har jo allerede tidligere vist sig magtesl $\varnothing$ se over for probandernes kriminalitet.

Der er en svag, men formentlig klar tendens til, at fanger fra negative hjem hyppigere end fanger fra positive hjem genindsættes og dømmes til fængsel, forvaring og lignende.

\section{S K O L E F O R H O L D}

Hovedparten har fået en undervisning, der svarer til den 7-årige folkeskoles. Kun 7 (5\%) har fået mere end 7 års under-

12) Bengt Börjeson betoner, i forbindelse med en lignende problemstilling, betydningen af de bagved liggende hypoteser, „Om påföljders verkningar", Stockholm 1966, s. 88 f. 
visning. 19 (14\%) har gået i hjælpeskole. 48 (35\%) har skiftet skole mere end én gang.

Halvdelen (67) er registreret som skulkere. Disse fanger har også på en række andre punkter negative forhold (fjernet fra hjemmet af børneværnet, r $\phi$ mningskriminalitet). De er hyppigt i recidivgruppe $B$.

$22(16 \%)$ har siddet over. Det er de dårligt begavede og probanderne fra negative milieuer. Fortrinsvis gruppe B.

De indhentede skoleudtalelser giver en samlet vurdering af skoleforholdene. Halvdelen har fået negative bed $\varnothing$ mmelser.

Tabel 15. Børneskolens vurdering.

$\begin{array}{lrr}\text { Positiv } & 22 & 16 \% \\ \text { Negativ } & 70 & 51 \% \\ \text { Neutral } & 34 & 25 \% \\ \text { Ingen } & 11 & 8 \% \\ \text { I alt } & 137 & 100 \%\end{array}$

De negativt bed $\phi$ mte er ofte begyndt på kriminalitet tidligt og har en stor IF. Recidivgruppe B dominerer.

A L K O H O L, IN T E L L I GEN S M. M.

I 43 tilfælde $(31 \%)$ er det oplyst, at fangens alkoholforbrug er af en sådan størrelse, at det må karakteriseres som misbrug, eller at det må antages, at hans $\phi$ konomi er blevet væsentlig belastet heraf. Den foretagne vurdering kan formentlig karakteriseres som streng, hvorfor gruppen er relativt stor. Det er bemærkelsesværdigt, at denne gruppe ikke falder hyppigere tilbage end andre fanger.

$25 \%$ af fangerne er af den mentalundersøgende læge anset for under normalt begavet. Hvor der ikke foreligger en klinisk vurdering er IK 90 benyttet som sondringsgrundlag. Også i denne gruppe finder man den sædvanlige fordeling af tilbagefald.

47 af probanderne $(34 \%)$ er i mentalunders $\phi$ gelsen karakteriset som psykopatiske, grænsepsykopatiske, karakterinsufficiente, henhørende under straffelovens $\S 17$ eller lignende. Ved læsningen af erklæringerne får man indtryk af, at en ikke ringe del af lægerne har været tilbageholdende med anvendelsen af disse diagnoser. Under gennemgangen af Rigsregistraturen blev også senere mentalunders $\phi$ gelser gennemset. De er ikke anvendt, men det konstateredes, at adskillige af de andre fanger senere er blevet anset for karakterdefekte, karakterneurotikere eller lignende. De recidiverer hurtigt og især til genindsættelse og forvaring $\mathrm{m}$. $\mathrm{m}$. 


\section{A R B E J D S F O R H O L D}

Godt halvdelen har haft skiftende arbejdsart.

52 \% har været 12 måneder eller derover på én arbejdsplads. De, der kun har været kort tid i en plads, er fors $\phi$ mmeligt opdraget, skulkere og børneværnets problembørn. De recidiverer hurtigt og hyppigt, især til grupperne B og C. I modsætning hertil har de, der har været lang tid i en plads, en god prognose, recidivgrupperne A og D.

Tabel 16. Arbejdsgiverbed $\varnothing$ mmelse.

Positiv vurdering

Negativ vurdering

Neutral vurdering

Ingen vurdering

I alt $i$ arbejde

\section{1}

50

19

35

135
$23 \%$

$37 \%$

$14 \%$

$26 \%$

$100 \%$

Fanger, der har fået positive udtalelser fra arbejdsgiveren, har også positive vurderinger i skolen og på opdragelseshjemmet. De recidiverer hurtigt til genindsættelse.

$76(55 \%)$ af fangerne har været arbejdsl $\varnothing$ se i en ikke ubetydelig del af den kriminelle periode.

\section{A F S L U T T E N D E B E M E R K N IN G E R}

Visse af faktorerne kan benyttes som grundlag for en kvalitativ vurdering. Man finder, at de negative hjem særlig karakteriseres af belastede forældre og fors $\varnothing$ mmelig opdragelse, at de negative skoleforhold særlig findes hos skulkerne, at negative forhold på opdragelseshjemmene er forbundet med r $\phi$ mningskriminalitet, stor interneringstæthed (både IL og IF), ophold på flere hjem og mange r $\varnothing$ mninger, og at de negative arbejdsforhold særlig viser sig ved skiftende arbejdsplads.

Det viser sig endvidere, at fanger, der er registreret med sådanne ,negative“ faktormanifestationer, i særlig h $\phi j$ grad recidiverer til fængsel, forvaring og lignende.

Hvis man udelukkende anvender recidivet som kriterium, må man konkludere, at den hehandling som ungdomsfængslet har givet disse fanger, er mindre effektiv end den, fanger med en anden baggrund får. Dermed er naturligvis intet sagt om, at de andetsteds kunne have fået en bedre behandling.

De fanger, der har haft negative forhold på opdragelseshjemmene, udg $\phi \mathbf{r}$ også kernen i de andre negative grupper. De børn eller unge, som har voldt børne- og ungdomsforsorgen st $\varnothing$ rst problemer, påvirkes altså, $\mathrm{i}$ forhold til de andre, mindre af ungdomsfængslets bestræbelser for resocialisering.

Vagn Greve.

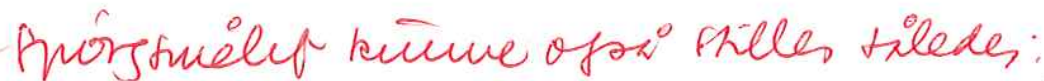

